\title{
EFEKTIVITAS STRATEGI INQUIRY DALAM MENINGKATKAN HASIL BELAJAR MAHASISWA MATA KULIAH SISTEM INFORMASI PERBANKAN
}

\author{
Nurbaiti Sirait \\ Program Studi Ekonomi Islam Fakultas Ekonomi dan Bisnis Islam UIN Sumatera \\ Utara \\ nurbaiti@uinsu.ac.id
}

\begin{abstract}
This study aims to know the student learning outcomes by using brainstorming method, conventional methods and knowing the difference between both of the 2 learning methods in the course of banking information systems. The objects are the students of semester V of Islamic Economics Program about 62 students with random sampling. In this research, the researchers succeeded in obtaining the values for the normality test in the experimental class on the pre-test obtained Lstat $=0.122$, while in the post-test Lstat $=0,093$ and for the control class on the pre-test Lstat $=0.129$, while in the post-test 0.102 , then the Ltabel $=0.159$ with the two classes having the same number of students, means the data is normally distributed. For homogeneity test the value of pre-test obtained Fstat $=1.61$ and the value of post-test diperleh Fhitung $=1.17$, while for Ftabel $=1.84$, which means the two samples each homogeneous. As for the hypothesis test t obtained price $t$ count $=2.389$ and ttable $=2,000$. Which means t-stat $>t$-table, that is 2,389 $>$ 2,000 means there are differences in learning outcomes in banking information system courses that are taught by brainstorming and conventional methods.
\end{abstract}

Keywords : learning method, brainstorming

\begin{abstract}
Abstrak
Penelitian ini bertujuan untuk mengetahui hasil belajar mahasiswa dengan menggunakan metode brainstorming, konvensional dan perbedaan antara kedua metode terhadap mata kuliah sistem informasi perbankan. Objek penelitian ini mahasiswa semester V Program Studi Ekonomi Islam sebanyak 62 orang dengan random sampling. Dalam penelitian ini, peneliti berhasil memperoleh nilai untuk uji normalitas pada kelas eksperimen pada pre-tes didapat $\mathrm{L}_{\text {hitung }}=0,122$, sedangkan pada pos-tes $\mathrm{L}_{\text {hitung }}=0,093$ dan untuk kelas kontrol pada pre-tes $\mathrm{L}_{\text {hitung }}$
\end{abstract}


$=0,129$, sedangkan pada pos-tes 0,102 , kem'udian harga $\mathrm{L}_{\text {tabel }}=0,159$ dengan kedua kelas tersebut yang mempunyai jumlah mahasiswa yang sama, berarti data berdistribusi normal. Untuk uji homogenitas nilai pre-tes diperoleh $\mathrm{F}_{\text {hitung }}=1,61$ dan nilai pos-tes diperleh $F_{\text {hitung }}=1,17$, sedangkan untuk $F_{\text {tabel }}=1,84$, yang berarti kedua sampel masing-masing homogen. Sedangkan untuk uji hipotesis t didapat harga $t_{\text {hitung }}=2,389$ dan $t_{\text {tabel }}=2,000$. Yang berarti $t_{\text {hitung }}>t_{\text {tabel }}$, yaitu 2,389 2,000 berarti terdapat perbedaan hasil belajar pada mata kuliah sistem informasi perbankan yang diajar dengan metode brainstorming dan konvensional.

\section{Kata kunci : metode belajar, brainstorming}

\section{Pendahuluan}

Pendidikan merupakan hal terpenting dan menjadi peran terpenting dalam kehidupan manusia. Pendidikan mengajarkan manusia untuk mampu memanfaatkan sumber daya yang ada secara optimal dan bijaksana, sehingga pendidikan berperan penting mengajarkan manusia untuk bertahan hidup.

Para pendiri bangsa ini sangat mengerti pentingnya pendidikan dari bangsa ini. Untuk itulah pendidikan ditempatkan di dalam Pembukaan Undang-Undang Dasar 1945. Tujuan kehidupan berbangsa dan bernegara tidak hanya ditujukan untuk menciptakan kesejahteraan umum, tetapi juga mencerdaskan kehidupan bangsa. ${ }^{1}$

Karena pentingnya pendidikan bagi masyarakat Indonesia, masyarakat menuntut kualitas pendidikan yang tinggi. Namun, di mata dunia, mutu pendidikan Indonesia ternyata masih rendah dibandingkan dengan negaranegara lainnya, khususnya di Asia Tenggara.

Dalam dunia pendidikan, proses pembelajaran memiliki peranan penting yaitu untuk menambah ilmu pengetahuan, keterampilan, serta penerapan konsep diri. Pembelajaran merupakan suatu kegiatan yang dilakukan oleh pendidik dengan sedemikian rupa sehingga tingkah laku peserta didik dapat berubah kearah yang lebih baik. Keberhasilan proses pembelajaran tercermin dalam peningkatan hasil belajar. 
Untuk mencapai hasil belajar, dibutuhkan peran aktif seluruh komponen pendidikan terutama peserta didik yang berperan sebagai input sekaligus sebagai output, serta pendidik sebagai fasilitator.

Berdasarkan data The Learning Curve Pearson 2014, sebuah lembaga pemeringkatan pendidikan dunia, memaparkan bahwa Indonesia menduduki posisi bontot alias akhir dalam mutu pendidikan di seluruh dunia. Indonesia menempati posisi ke-40 dengan indeks rangking dan nilai secara keseluruhan yakni minus 1,84 . Sementara pada kategori kemampuan kognitif indeks rangking 2014 versus 2012, Indonesia diberi nilai -1,71. Sedangkan untuk nilai pencapaian pendidikan yang dimiliki Indonesia, diberi skor -2,11. Posisi Indonesia ini menjadikan yang terburuk. Dimana Meksiko, Brasil, Argentina, Kolombia, dan Thailand, menjadi lima negara dengan rangking terbawah yang berada di atas Indonesia. $^{2}$

Rendahnya perhatian peserta didik pada penyampaian materi yang dilakukan oleh guru berdampak pada rendahnya hasil belajar peserta didik di sekolah. Guru merupakan kunci dalam proses pembelajaran sebagai pemilih media pembelajaran di kelas.

Tinggi atau rendahnya perhatian peserta didik pada proses pembelajaran tergantung pada pemilihan media yang digunakan. Dengan menggunakan media yang lebih menarik tentu juga akan membuat peserta didik lebih tertarik untuk memperhatikan pembelajaran, peserta didik juga mudah bosan jika menggunakan media yang begitu begitu saja. Oleh karena itu proses pembelajaran tergantung pada pemilihan media yang digunakan dalam proses pembelajaran.

Berbagai kendala dan hambatan banyak muncul dalam bidang pendidikan, yaitu dari dalam dan dari luar. Permasalahan banyak yang berawal dari dalam dunia pendidikan itu sendiri. Tenaga pendidik, peserta didik, kurikulum, dan fasilitas, serta strategi pembelajaran yang digunakan merupakan beberapa hal yang sering menimbulkan permasalahan di dunia pendidikan Indonesia.

Tenaga pendidik yang kurang profesional menjadi satu masalah yang harus segera diperbaiki. Strategi pembelajaran yang kurang tepat disertai dengan 
tenaga pendidik yang kurang profesional tentunya akan menghambat harapan dan tujuan dari adanya pendidikan.

Sejalan dengan apa yang diungkapkan oleh Rokhman, Pendidikan adalah media terbaik untuk membangun bangsa menjadi bangsa yang besar di semua sektor. ${ }^{3}$ Dalam dekade terakhir, upaya reformasi dalam ilmu pendidikan semakin hadir untuk menjadi perhatian seperti pemodelan dan pembelajaran sehingga dapat membantu mereka mengembangkan epistemologi mereka. ${ }^{4}$

Salah satu upaya untuk memperbaiki dan meningkatkan kualitas pendidikan bangsa Indonesia dapat membandingkan pendidikannya dengan negara lain yang kualitas pendidikannya jauh lebih baik. Hasil perbandingan itu, selanjutnya dapat dijadikan acuan dalam melakukan review secara objektif dan arif terhadap proses dan hasil pendidikan yang telah diterapkan pada seluruh jenjang pendidikan yang ada, untuk kemudian melakukan perbaikan atau pengembangan sesuai dengan tuntutan era global.

Setiap proses belajar yang dilaksanakan oleh peserta didik akan menghasilkan hasil belajar. Dalam proses pembelajaran dosen sebagai pengajar sekaligus pendidik memegang peranan dan tanggung jawab yang besar dalam rangka membantu meningkatkan keberhasilan peserta didik dalam mencapai tujuannya.

Hasil belajar yang baik hanya dicapai melalui proses belajar yang baik pula. Jika proses belajar tidak optimal sangat sulit diharapkan terjadinya hasil belajar yang baik. Kompetensi sosial dosen sangat diperlukan dalam pemebajaran khususnya dalam mata pelajaran Sejarah Kebudayaan Islam, sebab dalam penyampaian sejarah diperlukan kemampuan komunikasi yang efektif, empatik, dan santun.

Mampu mengkomunikasikan hasil-hasil inovasi pembelajaran. Dan mampu membangun hubungan sosial dengan pendidik lain. Kemampuan sosial dosen dalam melaksanakan tugasnya sangat berperan penting dalam peningkatan hasil belajar mahasiswa. 
Bukan hanya itu, keberhasilan atau tidaknya pendidikan salah satu yang mempengaruhinya adalah faktor yang mendukung pelaksanaan pendidikan itu sendiri. Apabila timbul permasalahan dalam pendidikan, maka dosen harus dapat mengklasifikasikan masalah tersebut ke dalam faktor-faktor yang ada. Apabila seluruh faktor telah dipandang baik terkecuali faktor metode ini, maka dosen harus pandai merinci dan mengklasifikasikan ke dalam klasifikasi masalah metode pendidikan yang lebih kecil dan terperinci lagi.

Ada banyak sekali metode yang dapat digunakan oleh dosen ketika melaksanakan proses pembelajaran antara lain metode ceramah, metode diskusi, metode qisah, metode demonstrasi, metode brainstorming, metode tanya jawab, metode bermain peran dan lain sebagainya.

Idealnya jika dosen menggunakan metode yang bervariasi dalam melaksanakan kegiatan pembelajaran, maka hasil belajar yang diperoleh mahasiswa akan lebih meningkat dengan cara memberikan kesempatan kepada mahasiswa untuk terlibat langsung ke dalam kegiatan belajar secara efektif.

\section{Hasil Belajar Mahasiswa}

Belajar merupakan suatu proses perubahan tingkah laku sebagai hasil interaksi Individu dengan lingkunganya dalam memenuhi kebutuhan hidup. Belajar adalah suatu proses inti dalam dunia pendidikan.

Menurut Dimyati dan Moedjiono belajar merupakan tindakan perilaku siswa yang kompleks. Sebagai tindakan, maka belajar hanya dialami oleh siswa sendiri. Siswa adalah penentu terjadinya proses belajar. Menurut Trianto proses belajar terjadi melalui banyak cara baik disengaja maupun tidak disengaja dan berlangsung sepanjang waktu dan menuju pada suatu perubahan pada diri pembelajar.

Hasil belajar adalah kemampuan yang diperoleh anak setelah melalui kegiatan belajar. Belajar itu sendiri merupakan suatu proses dari seseorang yang berusaha memperoleh suatu bentuk perubahan perilaku yang reratif menetap. Dalam kegiatan belajar yang terprogram dan terkontrol. Yang disebut kegiatan pembelajaran atau kegiatan intruksional. ${ }^{5}$ Tujuan belajar telah ditetapkan lebih 
dahulu oleh pendidik. Anak yang berhasil dalam belajar ialah yang berhasil mencapai tujuan-tujuan pembelajaran atau tujuan-tujuan intruksional.

Menurut Bloom Benjamin S. ${ }^{6}$, ada tiga ranah (domain) hasil belajar, yaitu kognitif, afektif, dan psikomotorik. Menurut A.J Romiszowski hasil belajar merupakan keluaran (outputs) dari berupa bermacam-macam informasi sedangkan keluarannya adalah perbuatan atau kinerja.

Penilaian hasil belajar oleh pendidik dapat dilakukan terhadap program, proses, dan hasil belajar. Penilaian program bertujuan untuk menilai efektivitas program yang dilaksanakan, penilaian proses bertujuan untuk mengetahui aktivitas dan partisipasi peserta didik dalam pembelajaran, dan penilaian hasil bertujuan untuk mengetahui hasil belajar atau pembentukan kompetensi peserta didik.

Seluruh penilaian dilakukan oleh pendidik untuk mengetahui kemajuan dan hasil belajar peserta didik, mendiagnosis kesulitan belajar, memberikan umpan balik untuk memperbaiki proses pembelajaran, dan menentukan kenaikan kelas bagi setiap peserta didik.

\section{Starategi Pembelajaran}

Pembelajaran dengan penyelidikan atau yang sering dikenal dengan istilah inquiry learning merupakan suatu metode pembelajaran yang mengenalkan siswa pada penyelesaian suatu masalah dalam proses pembelajaran.

Model pembelajaran adalah suatu perencanaan atau suatu pola yang digunakan sebagai pedoman dalam merencanakan pembelajaran di kelas atau pembelajaran dalam tutorial dan untuk menentukan perangkat-perangkat pembelajaran termasuk buku, film, komputer, kurikulum, dan lain-lain.

Suatu model pembelajaran adalah merupakan sebuah desain untuk membantu dalam mencapai tujuan pembelajaran yang diinginkan. ${ }^{7}$ Strategi pembelajaran inquiry adalah rangkaian kegiatan pembelajaran yang menekankan pada proses berpikir secara kritis dan analitis untuk mencari dan menemukan sendiri jawaban dari suatu masalah yang dipertanyakan. ${ }^{8}$ 
Discovery learning berbeda dengan inquiry learning. Dalam discovery learning, ada pengalaman yang disebut "Ahaa experience" yang dapat diartikan seperti, "Nah, ini dia". Sebaliknya, inquiry tidak selalu sampai proses tersebut. Hal ini karena proses akhir discovery learning adalah penemuan, sedang inquiry learning proses akhir terletak pada kepuasan kegiatan meneliti. Discovery merupakan bagian dari Inquiry, atau inquiry merupakan perluasan proses discovery yang digunakan lebih mendalam. ${ }^{9}$

Kata inkuiri atau dalam istilah lain disebut inquire (enquire), menurut kamus Oxford bahasa Inggris berarti penyelidikan atau menanyakan keterangan untuk memperoleh informasi. Inquiry merupakan model pembelajaran yang berupaya menanamkan dasar berpikir ilmiah pada peserta didik, sehingga dalam prosesnya peserta didik lebih banyak belajar sendiri, mengembangkan kreativitas peserta didik dalam memahami dan memecahkan masalah. ${ }^{10}$

Inkuiri merupakan suatu teknik atau cara yang digunakan guru untuk mengajar di depan kelas. Contoh pelaksanaanya seperti berikut, guru membagi tugas meneliti suatu masalah ke kelas. Peserta didik dibagi menjadi beberapa kelompok dan masing-masing kelompok mendapat tugas tertentu yang harus dikerjakan. Kemudian mereka mempelajari, meneliti maupun membahas tugasnya bersama, kemudian membuat laporan yang tersusun dengan baik. ${ }^{11}$

\section{Metode Pembelajaran}

Metode mengajar adalah adalah sebuah pengetahuan tentang cara-cara mengajar yang dipergunakan oleh seorang pendidik atau instruktur. Pengertian lain adalah tekhnik pengkajian yang dikuasai oleh pendidik untuk mengajar atau menyajikan bahan pelajaran kepada peserta didik di dalam kelas, baik secara individual ataupun kelompok, agar pelajaran dapat diserap, dipahami dan dimamfaatkan oleh pesertadidik yang baik. Makin baik metode mengajar, maka makin efektif pula pencapaian tujuan.

Surjosubroto menegaskan, metode pengajaran adalah cara-cara pelaksanaan proses pengajaran atau soal bagaimana tekhniknya suatu bahan pengajaran yang diberikan kepada peserta didik. 
Lima macam faktor yang mempengaruhi penggunaan suatu metode mengajar sebagai berikut: a) tujuan yang berbagai jenis dan fungsinya b) peserta didik yang berbagai tingkat kematangannya c) situasi yang berbagai keadaannya d) fasilitas yang berbagai macam kualitas dan kuantitasnya e) pribadi pendidik serta kemampuan profesionalnya yang berbeda-beda. ${ }^{12}$

Dari kutipan diatas dapat dipahami bahwa, metode dapat digunakan untuk merealisasikan strategi yang telah ditetapkan dan penggunaan metode yang tepat akan turut menentukan efektivitas dan efesiensi pembelajaran. Untuk itu, dalam menentukan metode mengajar merupakan suatu komponen yang sangat penting sebelum proses belajar mengajar berlangsung. Dengan demikian pendidik harus dapat menguasai berbagai metode mengajar sesuai yang telah dituntut oleh pokok bahasan tertentu, sebab tanpa metode mengajar yang tepat, maka proses mengajar akan sia-sia.

Begitu pentingnya metode dalam proses belajar mengajar, maka yang perlu mendapat perhatian adalah bagaimana metode itu menimbulkan aktifitas pada siswa, menumbuhkan semangat untuk menguasai pelajaran, sehingga proses pembelajaran berlangsung mencapai tujuan pengajaran. Pemilihan metode dipengaruhi oleh banyak faktor, seperti tujuan yang akan dicapai, materi yang disajikan, alat dan fasilitas yang tersedia, kemampuan pendidik menggunakan metode tersebut serta situasi dan kondisi yang ada.

\section{Keunggulan dan Kelemahan Strategi Pembelajaran Inkuiri}

Pembelajaran inkuiri merupakan pembelajaran yang dianjurkan, karena strategi ini memiliki beberapa keunggulan antara lain:

a). Pembelajaran inkuiri menekankan pada pengembangan aspek kognitif,afektif, dan psikomotor secara seimbang, sehingga pembelajaran ini dianggap lebih bermakna.

b) Pembelajaran inkuiri memberikan ruang kepada peserta didik untuk belajar sesuai dengan gaya belajar mereka.

3) Inkuiri merupakan strategi yang dianggap sesuai dengan perkembangan psikologi belajar modern yang menganggap belajar adalah proses perubahan tingkah laku berkat adanya pengalaman. 
4) Pembelajaran ini dapat melayani kebutuhan peserta didik yang memiliki kemampuan di atas rata-rata. Artinya, kemampuan peserta didik yang memiliki kemampuan belajar bagus tidak akan terhambat oleh peserta didik yang lemah dalam belajar. Di samping memiliki keunggulan, pembelajaran inkuiri juga memiliki kelemahan diantaranya sebagai berikut: a) Jika menggunakan strategi ini maka akan sulit untuk mengontrol kegiatan dan keberhasilan peserta didik. b) Pembelajaran inkuiri sulit untuk direncanakan karena terbentur dengan kebiasaan peserta didik dalam belajar. c) Dalam mengimplementasikan pembelajaran inkuiri memerlukan waktu yang panjang sehingga pendidik sering sulit menyesuaikan dengan waktu pembelajaran yang telah ditentukan. d) Selama kriteria keberhasilan belajar masih ditentukan oleh kemampuan peserta didik menguasai materi, maka pembelajaran inkuiri akan sulit diimplementasikan.

\section{Metode Brainstorming}

Brainstorming adalah cara lain yang digunakan oleh perusahaanperusaahaan untuk menghasilkan ide-ide pada masa kini. Brainstorming adalah mengumpulkan sekelompok orang, dengan tujuan menghasilkan pikiran-pikiran yang baru.

Menurut Isroy, Brainstroming adalah piranti perencanaan yang dapat menampung kreativitas kelompok dan sering digunakan sebagai alat pembentukan untuk mendapatkan ide-ide yang banyak, dan metode brainstorming merupakan salah satu cara mendapatkan sejumlah ide yang mudah dan menyenangkan para pesertanya. Pada dasarnya brainstorming adalah salah satu bentuk diskusi kelompok yang bertujuan untuk mencari solusi masalah

Menurut Guntar, Teknik brainstorming adalah teknik untuk menghasilkan gagasan yang mencoba mengatasi segala hambatan dan kritik. Kegiatan ini mendorong munculnya banyak gagasan, termasuk gagasan yang nyeleneh, liar, dan berani dengan harapan bahwa gagasan tersebut dapat menghasilkan gagasan yang kreatif. Brainstorming sering digunakan dalam diskusi kelompok untuk memecahkan masalah bersama. Brainstorming juga dapat digunakan secara individual. Sentral dari brainstorming adalah konsep menunda keputusan. 
Menurut Roestiyah, metode Brainstorming adalah suatu metode atau mengajar yang dilaksanakan oleh guru di dalam kelas. Ialah dengan melontarkan suatu masalah ke kelas oleh guru, kemudian siswa menjawab atau menyatakan pendapat, atau komentar sehingga mungkin masalah tersebut berkembang menjadi masalah baru, atau dapat diartikan pula sebagai satiu cara untuk mendapatkan banyak ide dari sekelompok manusia dalam waktu yang singkat. 1

Istilah yang relatif baru diperkenalkan dalam metode pendidikan ialah curah pendapat (brainstorming). ${ }^{13}$ Curah pendapat adalah salah satu bentuk berfikir kreatif sehingga pertimbangan memberikan jalan untuk berinisiatif kreatif. Curah pendapat (brainstorming), adalah teknik pembelajaran yang dilakukan dalam kelompok yang peserta didiknya memiliki latar belakang pengetahuan dan pengalaman yang berbeda-beda. ${ }^{14}$ Kegiatan ini dilakukan untuk menghimpun gagasan dan pendapat dalam rangka menentukan dan memilih berbagai pernyataan sebagai jawaban terhadap pertanyaan yang berkaitan dengan kebutuhan belajar, sumber-sumber, hambatan dan lain sebagainya.

Menurut Kang dan Song, dalam buku Suprijanto, Pendidikan Orang Dewasa curah pendapat adalah teknik diskusi kelompok dimana anggota menyatakan sebanyak mungkin ide-ide atau gagasan tertentu tanpa hambatan dan pertimbangan aplikasi praktisnya. ${ }^{15}$ Spontanitas dan kreatifitas merupakan bagian penting dalam curah pendapat. Rostiyah N.K. di dalam buku Istarani, menyatakan bahwa brainstorming adalah suatu metode atau suatu cara mengajar yang dilakukan oleh pendidik di dalam kelas dengan melontarkan suatu masalah, kemudian mahasiswa menjawab atau menyatakan pendapat, atau komentar sehingga memungkinkan masalah tersebut berkembang menjadi masalah baru, atau dapat pula sebagai suatu cara untuk mendapatkan banyak ide dari sekelompok manusia dalam waktu yang singkat. ${ }^{16}$

Berbeda dengan group investigation di mana gagasan dari seseorang dapat ditanggapi dalam pengertian didukung, dilengkapi, dikurangi, atau tidak disepakati oleh peserta lain, pada penggunaan metode brainstorming pendapat orang lain tidak untuk ditanggapi. 
Dalam metode brainstorming, tiap peserta didik diberi kesempatan secara bergiliran untuk menyampaikan pernyataan tentang pendapat atau gagasannya. Peserta didik yang tidak menyatakan buah pikirannya tidak dibolehkan untuk mengkritik atau berdebat terhadap gagasan atau pendapat yang sedang disampaikan.

Pendapat atau gagasan itu dituliskan di papan tulis atau pada kertas lebar yang disediakan. Selesai ditulis, pendapat atau gagasan itu dikaji dan dinilai oleh kelompok tersebut atau oleh tim yang ditunjuk untuk melakukan kajian.

Tujuan dari penggunaan metode ini ialah untuk menguras habis apa yang difikirkan para mahasiswa dalam menanggapi masalah tersebut. Oleh karena itu, dalam pelaksanaan metode ini tugas pendidik adalah memberikan masalah yang mampu merangsang pikiran mahasiswa, sehingga mereka mampu menanggapi dan pendidik tidak boleh mengomentari bahwa pendapat mahasiswa itu benar atau salah juga tidak perlu disimpulkan.

\section{Hipotesis Penelitian}

Berdasarkan latar belakang, kajian teori, penelitian yang relevan dan kerangka berfikir di atas dapat dikemukakan hipotesis penelitian sebagai jawaban sementara untuk permasalah yang telah dirumuskan pada bagian terdahulu.

Adapun hipotesis dari penelitian ini adalah:

Ho : Tidak terdapat perbedaan yang signifikan antara hasil belajar mahasiswa dengan menggunakan metode brainstorming dan metode konvensional

$\mathrm{Ha}$ : Terdapat perbedaan yang signifikan antara hasil belajar mahasiswa dengan menggunakan metode brainstorming dan metode konvensional

\section{Metodologi Penelitian}

Menurut Sugiyono, terdapat empat bentuk penelitian eksperimen, yaitu: "Pre-Eksperimental, True-Eksperimental, Factorial Eksperimental, dan Quasi Eksperimental. ${ }^{17}$ Bentuk penelitian yang dipakai dalam penelitian ini adalah jenis penelitian eksperimen semu (Quasi Experimental).

Model pembelajaran yang akan diteliti dalam peningkatan hasil belajar mahasiswa adalah model pembelajaran inquiry. Pelaksanaan metode eksperimen 
ini dosen berkolaborasi bersama peneliti tentang materi yang akan disampaikan dengan menggunakan model pembelajaran inquiry di dalam kelas. Penelitian ini terdapat kelas eksperimen dan kelas kontrol. Kelas eksperimen diberi perlakuan (treatment) model pembelajaran kontekstual dan kelas kontrol diberikan perlakuan dengan model pembelajaran konvensional (treatment).

Rancangan yang digunakan dalam penelitian ini adalah Post-test only control design dimana rancangan ini terdiri dari dua kelompok kelas, kelas pertama adalah sebagai kelas eksperimen dan satu kelas yang lain sebagai kelas kontrol. Kelas eksperimen akan diberikan perlakuan yaitu dengan model pembelajaran inquiry sedangkan kelas kontrol diberikan perlakuan konvensional. Desain penelitian ini adalah penelitian Eksperimen. Penelitian ini dilaksanakan di Universitas Islam Negeri (UIN) Sumatera Utara Fakultas Ekonomi dan Bisnis Islam UIN-SU. Penentuan lokasi ini didasarkan atas pertimbangan lokasi penelitian merupakan tempat peneliti mengajar serta keterbatasan dana dan tenaga yang tersedia dalam penelitian ini.

Populasi penelitian ini adalah seluruh mahasiswa Program Studi Ekonomi Islam Semester V Fakultas Ekonomi dan Bisnis Islam UIN Sumatera Utarayang terdiri atas 4 kelas dan berjumlah 134 orang mahsiswa. Sedangkan sampel yang akan diambil dari populasi tersebut harus betul-betul representatif atau dapat mewakili Sampel penelitian sebanyak orang yang terdiri dari 2 kelas yaitu kelas A dan kelas B. A untuk kelas brainstorming sebanyak 31 orang dan kelas B untuk kelas konvensiona sebanyak 31 orang. Teknik pengambilan sampel dilakukan secara acak (random sampling).

Instrumen yang digunakan dalam penelitian ini adalah tes hasil belajar. Menurut Aiken, tes adalah alat untuk mengukur perilaku, atau kinerja seseorang. Alat ukur tersebut berupa serangkaian pernyataan yang diajukan kepada masingmasing subjek yang menuntut penemuan tugas-tugas kognitif (cognitive back). Bentuk tes yang digunakan berupa tes pilihan berganda yang terdiri dari 20 (dua puluh) butir soal dan memiliki option jawaban (a, b, c, d dan e). Setiap soal yang dijawab benar dikali seratus dan dibagi dua puluh (B x $\frac{100}{20}$ ). 
Tes yang diberikan kepada sampel penelitian terlebih dahulu diuji cobakan kepada yang bukan sampel. Hasil uji coba tersebut dianalisis untuk memperoleh validitas tes, reliabilitas, daya beda tes, dan taraf kesukaran sehingga dapat diketahui apakah tes tersebut dapat digunakan sebagai instrumen penelitian sesuai dengan persyaratan yang telah ditetapkan.

Tes berupa pilihan berganda yang berjumlah 20 soal yang diberikan kepada semua mahasiswa. Dikerjakan di dalam kelas sesuai dengan waktu yang telah ditentukan. Tes berbentuk pre-test dan post-test. Pre-test akan diberikan sebelum pembelajaran dimulai untuk melihat kemampuan awal mahasiswa pada kedua kelas tersebut.

Setelah perlakuan metode pembelajaran yang berbeda selesai dilakukan pada kedua kelas, maka akan diberikan post-test untuk melihat seberapa besar pengaruh metode pembelajaran tersebut terhadap hasil belajar. Bentuk soal antara pre-test dan post-test sama.

Teknik analisis data yang digunakan dalam penelitian ini adalah analisis perbedaan dengan menggunakan rumus uji $-\mathrm{t}$. sebelum melaksanakan uji $-\mathrm{t}$ terlebih dahulu melakukan uji normalitas dan homogenitas varians dua sampel.

\section{Hasil Penelitian}

Hasil belajar mahasiswa yang diperoleh peneliti ialah:

\section{Data Hasil Belajar Kelas Ekperimen}

Sebelum diberikan perlakuan penggunaan metode brainstorming pada kelas eksperimen yakni kelas A. Mahasiswa terlebih dahulu diberikan pre-tes untuk mengetahui kemampuan awal mahasiswa sebanyak 15 soal dengan menggunakan skala 100. Setelah diketahui kemampuan awal mahasiswa, selanjutnya mahasiswa kelas eksperimen diajarkan dengan menggunakan metode brainstorming. Pada pertemuan terakhir, mahasiswa diberikan post-tes untuk mengetahui hasil belajar mahasiswa sebanyak 15 soal dengan penilaian menggunakan skala 100. Berdasarkan data yang diperoleh menunjukkan bahwa mahasiswa kelas eksperimen sebelum diberikan perlakuan, diperoleh nilai rata-rata pre-tes sebesar 42,15 dengan standar deviasi 9,49 dan setelah ajarkan dengan metode 
brainstorming, diperoleh rata-rata nilai post-tes sebesar 80.43 dengan standar deviasi 195,36.

\section{Data Hasil Belajar Kelas Kontrol}

Sama halnya yang dilakukan dengan kelas eksperimen, berdasarkan data yang diperoleh bahwa mahasiswa kelas eksperimen sebelum diberikan perlakuan, diperoleh nilai rata-rata pre-tes sebesar 40,43 dengan standar deviasi 12,04 dan setelah ajarkan dengan strategi konvensional, diperoleh rata-rata nilai post-tes sebesar 71,60 dengan standar deviasi 228,02.

\section{Uji Persyaratan Analisis}

Uji prasyarat analisis yang dilakukan adalah uji normalitas dengan menggunakan uji liliefors dan uji homogenitas dengan uji $\mathrm{F}$.

1. Nilai Rata-rata dan Simpangan Baku

Adapun nilai rata-rata dari kedua kelas dapat diuraikan bahwa kelas ekperimen memperoleh nilai rata-rata pretest 42,15 dengan simpangan baku 9,49. Dan sedangkan nilai rata-rata posttest 80,83 dengan simpangan baku 13,98. Untuk kelas kontrol memperoleh nilai rata-rata pretest 40,43 dengan simpangan baku 12,04. Dan sedangkan nilai rata-rata posttest 71,60 dengan simpangan baku 15,10. Dalam mencari nilai rata-rata dan simpangan baku, peneliti menggunakan Microsoft excel dalam pencariannya. Untuk mencari nilai rata-rata rumusnya $=$ AVERAGE (sort1:sortn), sedangkan untuk mencari simpangan baku rumusnya adalah =STEDEV(sort 1 :sortn). Peneliti mengujinya secara manual dan menggunakan Microsoft excel dan hasil keduanya sama.

\section{Uji Normalitas}

Uji normalitas berfungsi untuk mengetahui apakah data-data hasil penelitian memiliki sebaran data yang berdistribusi normal. Sampel berdistribusi normal jika $\mathrm{L}_{\text {hitung }}<\mathrm{L}_{\text {tabel }}$ pada taraf $u=0.05$. Uji normalitas ini dilakukan terhadap dua kelas, yaitu :

a. Uji Normalitas Kelas Eksperimen 
Uji normalitas pada hasil pre-test dan pos-tes diperoleh nilai kritik L uji liliefors dengan $\mathrm{n}=31$ berarti diperoleh $\mathrm{L}_{\text {tabel }} \frac{0.886}{\sqrt{31}}=0.159$ dan taraf $\alpha=$ 0,05 .

b. Uji Normalitas Kelas Kontrol

Uji normalitas pada hasil pre-test dan pos-tes diperoleh nilai kritik L uji liliefors dengan $\mathrm{n}=31$ berarti diperoleh $\mathrm{L}_{\text {tabel }} \frac{0.886}{\sqrt{31}}=0.159$ dan taraf $\alpha=$ 0,05 .

3. Uji Homogenitas

Uji homogenitas data dilakukan untuk mengetahui apakah kelompok sampel yang digunakan dalam penelitian ini berasal dari ppoulasi yang homogen atau tidak, yakni apakah sampel yang digunakan dapat mewakili seluruh populasi yang ada. Untuk pengujian homogenitas digunakan uji kesamaan kedua varians yaitu uji $\mathrm{F}$ pada data pre-tes dan post-tes pada kedua sampel. Untuk pre-tes, diperoleh $\mathrm{F}_{\text {hitung }}<\mathrm{F}_{\text {tabel }}$ yakni $1.61<1.84$ pada taraf $u=0.05$. sedangkan untuk pos-tes diperoleh $1.67<1.84$ pada taraf $u=0.05$. Berdasarkan hasil perhitungan, dapat disimpulkan bahwa pada kelas eksperimen maupun kelas kontrol berasal dari populasi yang homogen. Hal ini berarti dapat digunakan sebagai sampel yang mewakili populasi.

\section{Uji Hipotesis}

Setelah diketahui bahwa untuk data hasil belajar kedua sampel memiliki sebaran yang berdistribusi normal dan homogen, selanjutnya dilakukan pengujian hipotesis. Pengujian hipotesis dilakukan pada data post-tes dengan menggunakan uji t. Hal ini dilakukan pada pos-tes saja dikarenakan hanya pada pos-tes perlakuaan yang berbeda pada kedua kelas tersebut. Adapun hasil pengujian data post-tes kedua kelas menunjukkan bahwa hasil pengujian hipotesis pada data posttes diperoleh $t_{\text {hitung }}>t_{\text {tabel }}$ yakni 2,389 $>2,0000$ pada taraf $u=0.05$. Dalam hal ini, $\mathrm{H}_{0}$ ditolak dan $\mathrm{H}_{\mathrm{a}}$ diterima berarti "Terdapat perbedaan hasil belajar mahasiswa mata kuliah sistem informasi perbankan menggunakan metode brainstormingdengan strategi konvensional”.

\section{Pembahasan Penelitian}


Adapun nilai rata-rata nilai pre-tes untuk kelas eksperimen adalah 42,15 dan untuk kelas kontrol adalah 40,43. Berdasarkan pengujian homogenitas yang dilakukan diperoleh bahwa kedua kelas memiliki data berdistribusi normal dan varians yang sama atau homogen. Berdasarkan itu, berarti kedua kelas tersebut dapat dibandingkan sebagai penelitian eksperimen.

Berdasarkan rata-rata nilai pos-tes kedua kelas, terlihat bahwa rata-rata nilai post-tes kelas eksperimen lebih tinggi bandingkan dengan rata-rata nilai posttes kelas kontrol. Untuk membuktikan apakah ada perbedaan hasil pembelajaran digunakan uji t. Hasil pengujian diperoleh $t_{\text {hitung }}>t_{\text {tabel }}$ yaitu 2,389 $>2,000$ pada taraf $\alpha=0,05$. Ini berarti $\mathrm{H}_{0}$ ditolak dan $\mathrm{H}_{\mathrm{a}}$ diterima, jadi dalam hal ini "Terdapat perbedaan hasil belajar mahasiswa pada mata kuliah sistem informasi perbankan menggunakan metode brainstorming dengan metode konvensional”.

Terlihat bahwa mahasiswa pada kelas eksperimen yang diajarkan dengan metode brainstorminglebih tertarik dan termotivasi untuk belajar.Hal ini dikarenakan, mahasiswa secara aktif ikut langsung dalam pembelajaran. Sedangkan pada kelas kontrol yang diajarkan dengan metodekonvensional tidak semua mahasiswa mampu menguasai materi pelajaran dengan baik dan sempurna. Hal ini dikarenakan mahasiswa tidak secara aktif dalam proses pembelajaran. Selain itu hanya sebagian mahasiswa yang mengikuti pembelajaran yang mengerti akan materi tersebut.

\section{Kesimpulan}

Penggunaan metode brainstorming ternyata cukup efektif untuk diterapkan. Hal ini dikarenakan mahasiswa terlibat langsung dalam proses. Adapun nilai rata-rata hasil belajar mahasiswa yang diberi perlakuan dengan metode brainstorming adalah untuk nilai pre-tes diperoleh rata-rata 42,15 dengan standar devisi 9,49 dan varians 90,04 sedangkan untuk nilai post-tes diperoleh rata-ratanya 80,43 dengan standar deviasi 13,98 dan varians 195,36. Untuk penggunaan strategi konvensional ternyata kurang efektif untuk diterapkan. Ini dikarenakan tidak semua mahasiswa mampu menguasai materi pelajaran dengan baik dan sempurna. 
Hal ini dikarenakan mahasiswa tidak terlibat langsung dalam pembelajaran. Adapun nilai rata-rata hasil belajar mahasiswa yang diberi perlakuan dengan menggunakan strategi konvensional adalah untuk nilai pre-tes diperoleh rata-rata 40,43dengan standar deviasi 12,04 dan varians 144,99 sedangkan untuk nilai post-tes diperoleh nilai rata-ratanya 71,60 dengan standar deviasi 15,10 dan varians 228,01. Berdasarkan uji statistik t pada data post-tes diperoleh $t_{\text {hitung }}>t_{\text {tabel }}$ yaitu 2,389 $>2,000$ pada taraf $\alpha=0,05$. Ini berarti $H_{0}$ ditolak dan $\mathrm{H}_{\mathrm{a}}$ diterima, jadi dalam hal ini "Terdapat perbedaan hasil belajar mahasiswa pada mata kuliah sistem informasi perbankan menggunakan metode brainstormingdengan strategi konvensional".

Berdasarkan hasil penelitian ini, maka penulis menyarankan bagi dosen mata kuliah sistem informasi perbankan agar memilih metode pembelajaran yang dapat menunjang keberhasilan belajar baik itu metode brainstorming atau yang lain pada setiap penyampaian materi tertentu agar dapat menunjang proses belajar mengajar yang lebih efisien dan hasil belajar mahasiswa dapat lebih meningkat. Sedangkan untuk mahasiswa yang ingin meneliti dengan judul yang sama, agar dapat mempertimbangkan karakteristik kelas masing-masing sehingga dapat dijadikan suatu perbandingan bagi dosen dalam meningkatkan hasil belajar.

${ }^{1}$ www.metrotvnews.com

\section{Catatan}

${ }^{2}$ www.okezone.com

${ }^{3}$ Rokhman Hum, M. \& Syaifudin, A., Character Education for Golden Generation 2045 National Character Building for Indonesian Golden Years. (Procedia - Social and Behavioral Sciences, 2014) HIm. 1162

${ }^{4}$ Baek \& Schwarz, The Influence of Curriculum, Instruction, Technology, and Social Interactions on Two Fifth-Grade Students??? Epistemologies in Modeling Throughout a ModelBased Curriculum Unit. (Journal of Science Education and Technology, 2015) hlm. 216

\footnotetext{
${ }^{5}$ Mulyono Abdurrahman. (2009:37-38),

${ }^{6}$ Bloom,Benjamin S. (1966:6)
} 
${ }^{7}$ (Trianto, 2007).

${ }^{8}$ (Wina Sanjaya, 2014).

${ }^{9}$ (Agus Suprijono, 2009).

${ }^{10}$ (Kokom Komalasari, 2013).

11 (Roestiyah dan Yumiati, 1985).

${ }^{12}$ Surjosubroto (2007:43)

${ }^{13}$ Suprijanto. Pendidikan Orang Dewasa. (Jakarta: PT. Bumi Aksara, 2007) hlm.122.

${ }^{14}$ Sudjana S. Metode dan Teknik Pembelajaran Partisipatif. (Bandung: Falah Production, 2000) hlm. 86.

\footnotetext{
${ }^{15}$ Suprijanto, Pendidikan Orang Dewasa. (Jakarta: PT. Bumi Aksara, 2007) hlm.122.

${ }^{16}$ Istarani. Kumpulan 39 Metode Pembelajaran. (Medan: CV. Iscom Medan, 2012) hlm. 70

${ }^{17}$ Sugiyono (2013:108-109)
}

\section{Daftar Pustaka}

Baek, H., \& Schwarz, C. V. (2015). The Influence of Curriculum, Instruction, Technology, and Social Interactions on Two Fifth-Grade Students??? Epistemologies in Modeling Throughout a Model-Based Curriculum Unit. Journal of Science Education and Technology, 24(2-3), 216-233. https://doi.org/10.1007/s10956-014-9532-6

Istarani. 2012. Kumpulan 39 Metode Pembelajaran. Medan: CV. Iscom Medan

Joyce, B. And Weil. 2000. Model of Teaching. Needham Heights: Allyn \& Bacon

Robins, Stephen P. 1996. Organizational Behavior: Concepts, Controversies, Applications. New York: Prentice Hall, Inc 
Rokhman, F., Hum, M. \& Syaifudin, A., 2014. Character Education for Golden Generation 2045 (National Character Building for Indonesian Golden Years). Procedia - Social and Behavioral Sciences.

S, Sudjana. 2000. Metode dan Teknik Pembelajaran Partisipatif. Bandung: Falah Production

Siddik, Dja'far. 2009. Pendidikan dan Transformasi Sosial. Bandung: CV. Perdana Mulya Sarana

Slavin, R. E. E., \& Cooper, R. 199). Improving intergroup relations: Lessons learned from cooperative learning programs. Journal of Social Issues, 55(4), 647-663. https://doi.org/10.1111/0022-4537.00140

Snelbecker, G. E. 1974. Learning Theory Instructional Theory and Psychoeducational Design. New York : Mc Graw Hill Book Co

Subini, Nini. 2012. Psikologi Pembelajaran . Yogyakarta: Mentari Pustaka

Sukardi. 2008. Metodologi Penelitian Pendidikan. Jakarta: Bumi Aksara

Suprijanto. 2007. Pendidikan Orang Dewasa. Jakarta: PT. Bumi Aksara

Thiagarajan, S. And Others. 1974. Instructional Development for Training Teachers of Exceptional Children: A Sourcebook. Minneapolis, Minnesota

Tilaar, H.A.R, 2002, Membenahi Pendidikan Nasional, Jakarta: Rinekacipta

Trif, L., 2015. Training Models of Social Constructivism. Teaching Based on Developing A Scaffold. Procedia - Social and Behavioral Sciences, 180(November 2014), pp.978-983

Viorica, C., 2015. Reflections on the Development of Responsible Learning by Capitalizing Student-Centered Educational Strategies. Procedia - Social and Behavioral Sciences, 191, pp.1947-1951 
681 | At-Tawassuth, Vol. III, No. 1, 2018: 662 - 681

Yen, T.S. \& Halili, S.H., 2015. Effective Teaching of Higher-Order Thinking (HOT) in Education. The Online Journal of Distance Education and eLearning, 3(2), April, pp.41-47. 